\title{
Kan Helse-Norge samles til ett rike?
}

\author{
Vi oversvømmes av informasjon, men er kanskje likevel på rett vei.
}

I mer enn ti år har jeg engasjert meg i å oppdatere og lage metodebøker for sykehus. Det er et lærerikt, tidkrevende og kontinuerlig arbeid som de fleste leger gjør i sin fritid. På hver sin lille tue sitter leger over hele landet og gjør det samme, fordi alle helseforetak skal ha dokumenter som styrer virksomheten.

Ved Oslo universitetssykehus har vi nå nærmere 100000 dokumenter i vår e-håndbok. Kvaliteten på dokumentene varierer selvsagt, og dubletter fra avdelinger med overlappende arbeidsoppgaver florerer. E-håndboken ligner mer og mer på internett, et system for styring som mangler en ansvarlig og aktiv redaksjon.

Nasjonalt kunnskapssenter for helsetjenesten har gjennom Helsebiblioteket brukt store ressurser på å samle medisinsk informasjon for helsepersonell og pasienter på et sted (1). En god tanke, men pasientinformasjonen som nå ligger ute, er oversatt fra BMJ Best Practice og kan på grunn av rettigheter ikke tilpasses norske forhold (2). At litteratursøk i Helsebiblioteket i tillegg bare gir begrenset tilgang til den nyeste medisinske litteraturen, er skammelig.

Helsedirektoratet publiserer i disse dager en helt ny versjon av Nasjonal faglig retningslinje for diabetes (3). I dette arbeidet er det lagt ned betydelige ressurser i å basere anbefalingene på et vitenskapelig grunnlag. Resultatet er imponerende - og skuffende. Prosessen har vært transparent, og omfattende dokumentasjon er gjennomgått, men jevnt over er det vitenskapelige grunnlaget for anbefalingene lav. Folkesykdommen diabetes har vært, og er, gjenstand for store, kostbare internasjonale studier. Likevel har man ikke nok kunnskap til å gi klare evidensbaserte råd om behandlingen. Hva da med alle de sykdommene som bare rammer noen hundre nordmenn $i$ året?

Det finnes alternativer når evidensbasert metodikk ikke er hensiktsmessig. Inspirert av Barnelegeforeningens Veileder i pediatri besluttet årsmøtet i Norsk endokrinologisk forening i 2013 å lage en veileder i endokrinologi. Endokrinologer fra hele landet har deltatt $\mathrm{i}$ arbeidet. Veilederen ble publisert desember 2015 (4). Det er tankevekkende når Kristian Hanssen, en nestor i norsk diabetesforskning og bidragsyter til Helse- direktoratets retningslinje for diabetes, i sin anmeldelse av veilederen skriver at vi har fått til det de ikke har klart (5). Vi har laget et mer brukervennlig produkt, til en ikke sammenlignbar kostnad.

\section{Legeforeningen på banen}

Legeforeningen har de siste årene mistet mye makt til Helsedirektoratet. Når Helsedirektoratet nå sliter med tidkrevende retningslinjeprosesser, har Legeforeningen en

\section{«Legeforeningen bør etablere en felles platt- form for publisering av veiledere»}

gyllen mulighet til å fronte faget. Foreningen bør stimulere og støtte de fagmedisinske foreningene $i$ arbeidet med å lage veiledere for utredning og behandling. Dette vil komme både behandlere, pasienter og helseforetak til nytte. Legeforeningen bør etablere en felles plattform for publisering av veiledere, med en nettversjon og applikasjoner for mobiltelefon og nettbrett. Det gir god oversikt for brukerne og det vil lette jobben med oppdateringer.

Hva med informasjon til pasienter? Helsenorge.no ble lansert for fem år siden. Pasientene bruker nettstedet aktivt, og i løpet av juni 2016 ble det registrert 1,4 millioner innlogginger (6). Det er her den elektroniske, fremtidsrettede kontakten mellom helsevesen og pasienter skal foregå. Direktoratet for e-helse beskriver sin samfunnsoppgave slik: «Å bidra til én helhetlig og kunnskapsbasert helse- og omsorgstjeneste som utnytter de teknologiske mulighetene og involverer innbyggere for å bidra til bedre helse, bedre resultater av helsehjelp og bedre utnyttelse av kapasitet» (7). Kan de lykkes? Går du inn på nettstedet, kan det se ut som de er godt på vei.

I prosjektet Felles nettløsning for spesialisthelsetjenesten skal det i løpet av året publiseres pasientinformasjon om sykdom- mer, utredning og behandling som gjelder for hele landet. Arbeidet er godt i gang og vil gi pasientene tilgang til oppdatert informasjon og samtidig være til stor avlastning for alle prosedyreskrivende helsearbeidere. Dette er et stort fremskritt for Helse-Norge.

Are Brean beskriver et kaos av veiledninger og retningslinjer (8). Tiden etter kaos kan være fruktbar, og jeg ser for meg en fremtid hvor Helsedirektoratet lager retningslinjer for prioriteringer og behandling av de store pasientgruppene, Direktoratet for e-helse samler og samkjører pasientinformasjon, Helsebiblioteket sikrer lik tilgang på medisinsk litteratur til alle, og Legeforeningen tar ansvar for å lage og huse veiledere for utredning og behandling innen de ulike spesialitetene. Det er en grei arbeidsdeling.

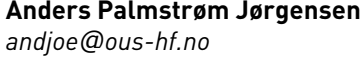

Anders Palmstrøm Jørgensen (f. 1965) spesialist $\mathrm{i}$ indremedisin og $\mathrm{i}$ endokrinologi, overlege og ph.d. ved Oslo universitetssykehus. Han er leder av Norsk endokrinologisk forening. Forfatter har fylt ut ICMJE-skjemaet og oppgir ingen interessekonflikter.

Litteratur

1. Helsebiblioteket. http://helsebiblioteket.no/ (30.8.2016)

2. Pasientinformasjon. http://helsebiblioteket.no/ pasientinformasjon (30.8.2016).

3. Helsedirektoratet. Nasjonale faglige retnings linjer. https://helsedirektoratet.no/retningslinjer (30.8.2016)

4. Jørgensen AP, Tazmini K, red. Nasjonal veileder i endokrinologi. Oslo: Norsk endokrinologisk forening, 2015.

5. Hanssen K. Imponerende veileder i endokrinologi. Tidsskr Nor Legeforen 2016; 136: 1020.

6. Bruksstatistikk juni 2016. http://helsenorgebeta. net/2016/07/bruksstatistikk-juni-2016/ (30.8.2016)

7. Om Direktoratet for e-helse. https://ehelse.no/ om-oss/om-direktoratet-for-e-helse [30.8.2016).

8. Brean A. Et kaos. Tidsskr Nor Legeforen 2016; 136: 687 .

Mottatt 14.7. 2016 og godkjent 6.9. 2016. Redaktør: Ragnhild Ørstavik.

Publisert først på nett. 